\title{
ARTICLES
}

\section{Her-2/neu Gene Amplification, Elevated mRNA Expression, and Protein Overexpression in the Metaplasia-Dysplasia-Adenocarcinoma Sequence of Barrett's Esophagus}

\author{
Axel Walch, Katja Specht, Karin Bink, Horst Zitzelsberger, Herbert Braselmann, \\ Markus Bauer, Michaela Aubele, Hubert Stein, Jörg Rüdiger Siewert, Heinz Höfler, \\ and Martin Werner
}

Institute of Pathology (AW, KB, MB, HH), and Department of Surgery (HS, JRS), Technische Universität München, Munich; and Institute of Pathology (AW, KS, KB, MA, HH, MW) and Institute of Radiation Biology (HZ, HB), GSF-National Research Center for Environment and Health, Neuherberg, Germany

SUMMARY: The importance of alterations of the Her-2/neu oncogene in the tumorigenesis of Barrett's adenocarcinoma (BCA) is discussed controversially. In the present study, we evaluated for the first time the Her-2/neu status in the metaplasia-dysplasiaadenocarcinoma sequence of BCA simultaneously at the DNA, mRNA, and protein level using resection specimens of 25 patients. The locus-specific Her-2/neu gene status was quantified by performing fluorescence in situ hybridization, and information about the ploidy status of chromosome 17 was obtained. Tissue sections from the same areas were used for quantitative RT-PCR (TaqMan RT-PCR) of laser-microdissected tumor cells and for immunohistochemistry to quantify Her-2/neu mRNA and oncoprotein expression. Her-2/neu gene amplification was observed in 35\% of BCA, and all of these samples showed strong overexpression of both mRNA and oncoprotein. A polysomy 17 without Her-2/neu gene amplification was observed in $52 \%$ of BCA, showing a normal or moderately elevated mRNA expression and no or weak immunopositivity. From 13 areas of high-grade dysplasia (HGD) we found four to be amplified for the Her-2/neu locus, whereas five showed a polysomy 17 . All four samples of HGD areas with Her-2/neu gene amplification displayed mRNA and strong oncoprotein overexpression; however, lower mRNA levels were seen than in the amplified BCA areas. None of the samples with low-grade dysplasia (LGD) showed a locus-specific Her-2/neu amplification, but polysomy 17 was present in four of eight cases. No changes were detected in BCA-associated intestinal metaplasia and squamous epithelium. In summary, only a locus-specific Her-2/neu gene amplification was associated with strong mRNA overexpression and strong membranous Her-2/neu immunostaining in BCA and HGD. A chromosome 17 polysomy, as found in the majority of BCA, led to no or weak mRNA overexpression and no or weak immunopositivity. In the metaplasia-dysplasia-adenocarcinoma sequence, a chromosome 17 polysomy without Her-2/neu gene amplification was already present in LGD. This may be a result of an early polyploidization, preceding the later genetic events, such as Her-2/neu gene amplification in HGD and BCA. (Lab Invest 2001, 81:791-801).

\begin{abstract}
G ene amplification and protein overexpression of Her-2/neu, a 185,000 molecular weight transmembrane tyrosine kinase, has been studied extensively in various tumor types. Because it has been shown that Her-2/neu amplification/overexpression has therapeutic and prognostic implications in breast cancer and other tumors (Ross and Fletcher, 1998), there is a growing demand for Her-2/neu analysis. However, the importance of Her-2/neu in the tumorigenesis of Barrett's adenocarcinoma (BCA) remains
\end{abstract}

Received September 13, 2000.

Address reprint requests to: Dr. Axel Walch, Institut für Allgemeine Pathologie und Pathologische Anatomie, Ismaninger Straße 22, D-81675 München, Germany.E-mail: axel.walch@lrz.tum.de unclear. In previous immunohistochemical studies, the prevalence of Her-2/neu overexpression varied widely from $11 \%$ to $73 \%$ of invasive BCA (al-Kasspooles et al, 1993; Flejou et al, 1994; Hardwick et al, 1995; Jankowski et al, 1992). Moreover, the association of Her-2/neu alterations with the histologically proposed metaplasia-dysplasia-adenocarcinoma sequence is obscure and controversial. Some studies suggest that Her-2/neu overexpression is a frequent and early event (al-Kasspooles et al, 1993; Jankowski et al, 1992), whereas others show it to be much less common and occurring relatively late in BCA tumorigenesis (Flejou et al, 1994).

Fluorescence in situ hybridization (FISH) is increasingly applied to detect the Her-2/neu gene amplifica- 
tion in tumor samples. Applying a locus-specific probe only, Her-2/neu gene amplification has recently been reported in 19\% of BCA (Brien et al, 2000). However, dual-color FISH with DNA probes complementary to the Her-2/neu gene and the centromere of chromosome 17 is necessary to distinguish a locus-specific gene amplification from chromosome 17 aneuploidy, which is important because aneuploid or increased tetraploid populations occur in more than $90 \%$ to $95 \%$ of BCA (Barrett et al, 1999).

The Her-2/neu gene amplification is usually associated with overexpression of the Her-2/neu gene product. In breast carcinoma, 3\% to $15 \%$ of cases, however, have been shown to display discordant results at the DNA and protein level (Jimenez et al, 2000). Especially in those cases that show a moderate immunostaining without genomic amplification, determination of Her-2/neu mRNA levels would be helpful.

A recently developed method, the real-time reverse transcriptase polymerase chain reaction (RT-PCR), based on TaqMan methodology, provides a new powerful tool for quantifying Her-2/neu gene expression. Very recently, we established quantitative (Q)RT-PCR for small microdissected tissue samples from archival material (Specht et al, 2001), now opening the possibility of investigating even premalignant lesions that usually consist of small cell populations.

In the present study, the Her-2/neu status in the metaplasia-dysplasia-adenocarcinoma sequence of BCA was evaluated for the first time simultaneously at the DNA, mRNA, and protein level. By performing dual-color $\mathrm{FISH}$, we quantified the Her-2/neu gene status and obtained information about the ploidy status of chromosome 17. Tissue sections from the same areas were used for QRT-PCR (TaqMan PCR) of laser-microdissected tumor cells and immunohistochemistry to quantify Her-2/neu mRNA and oncoprotein expression.

\section{Results}

Table 1 summarizes the chromosome 17 status and Her-2/neu gene copy number changes, mRNA level, and oncoprotein expression of the investigated BCA, high-grade dysplasia (HGD), low-grade dysplasia (LGD), and intestinal metaplasia (IM) samples, including normal squamous epithelium. An overview of the results for the $23 \mathrm{BCA}$ cases is given in Table 2. Figure 1 and Figure 2 illustrate the results of FISH and immunohistochemistry (IHC) in BCA and HGD, respectively. Figure 3 shows real-time amplification curves for two cases of BCA.

\section{FISH (Her-2/neu Gene Copy Number and Aneuploidy of Chromosome 17)}

Eight of 23 (35\%) BCA were amplified for the Her-2/ neu gene. All of the amplified BCA showed Her-2/neu signals as coalescent signal clusters consisting of more than 10 signals per nucleus in at least $30 \%$ of the total tumor area. In these BCA more than two centromere 17 signals were observed, indicating a chromo- some 17 polysomy in addition to Her-2/neu gene amplification (Fig. 1E). A polysomy 17 without gene amplification, according to the definition of more than two centromere 17 signals and more than two Her-2/ neu signals (ratio 1:1), was observed in 12 of $23(52 \%)$ BCA (Fig. 1C). Three of 23 (13\%) BCA showed no gene copy number changes (Fig. 1A). From 13 HGD areas, four displayed a Her-2/neu amplification (Fig. $2 \mathrm{~A}$ ), five of 13 areas showed a polysomy 17 , and in four of 13 areas no changes were observed. Eight LGD lesions were investigated, from which four were classified as polysomy 17 and the remaining four displayed a normal signal pattern. No changes were observed in the five IM areas or in all 13 samples of squamous epithelium (Table 1).

\section{Real-Time Quantitative Reverse Transcriptase Polymerase Chain Reaction (QRT-PCR) (Her-2/neu mRNA Level)}

In eight of 23 (35\%) laser-microdissected BCA, a strong Her-2/neu overexpression (5.42-83.57) was observed, two (9\%) showed a moderate overexpression (4.06-4.53), and $13(56 \%)$ showed a normal mRNA level (0.27-1.10). Two of 13 HGD lesions displayed a strong overexpression (6.24 and 29.96). In three HGD a moderate overexpression (2.35-3.70) and in eight a normal level (0.31-0.82) was observed. All eight LDG lesions displayed a normal mRNA level (0.37-1.50). The investigated IM areas (mean, 0.67) and all 13 samples of squamous epithelium (mean, 0.92) displayed a normal mRNA levels (Table 1).

\section{IM (Her-2/neu Oncoprotein Overexpression)}

According to the DAKO scoring system used, eight of $23(35 \%)$ BCA were scored as 3+ (Fig. 1F), five (22\%) as $2+$ (Fig. 1D), eight (35\%) as $1+$, and two (9\%) as 0 (Fig. 1B). Four of $13 \mathrm{HGD}$ areas were scored as 3+ (Fig. 2B), two as $2+$, six as $1+$, and one as 0 . From eight LGD lesions, seven were classified as $1+$ and one as 0 . Two of the IM areas was scored as $1+$, the remaining three as 0 . From the 13 samples of squamous epithelium, six were scored as $1+$ and seven as 0 (Table 1).

\section{Relationship between Her-2/neu Gene Copy Number Changes, Polysomy 17 and Her-2/neu mRNA Expression, and Her-2/neu Oncoprotein Expression}

The relationship between chromosome 17 status and Her-2/neu gene copy number changes, mRNA level, and oncoprotein expression of the BCA are presented in Figure 4. The relationship between the Her-2/neu gene, mRNA, and oncoprotein level in the metaplasiadysplasia-adenocarcinoma sequence of those cases showing an amplification or a polysomy 17 in BCA are shown in Figure 5.

In all samples of BCA showing Her-2/neu gene amplification, a strong mRNA overexpression (mean, 22.58) was observed. However, comparing FISH and $\mathrm{IHC}$, minor cell populations showing a polysomy 17 without Her-2/neu gene amplification and less inten- 
Table 1. Her-2/neu Status in Barrett's Adenocarcinoma ${ }^{a}$ and Associated Premalignant Lesions

\begin{tabular}{|c|c|c|c|c|c|c|c|c|c|}
\hline CASE & Lesion & pT & $\mathrm{pN}$ & M & G & Polysomy $17^{b}$ & $\begin{array}{l}\text { Her-2/neu }{ }^{b} \text { gene } \\
\text { amplification }\end{array}$ & QRT-PCR & $\mathrm{IHC}$ \\
\hline $\begin{array}{l}1 \\
1 \\
1\end{array}$ & $\begin{array}{l}\text { BCA } \\
L G D \\
\text { IM }\end{array}$ & 1 & 1 & $x$ & 3 & $\begin{array}{l}+ \\
+ \\
+\end{array}$ & $\begin{array}{l}- \\
- \\
-\end{array}$ & $\begin{array}{l}1.10 \\
1.04 \\
\text { n.d. }\end{array}$ & $\begin{array}{l}0 \\
0 \\
0\end{array}$ \\
\hline $\begin{array}{l}2 \\
2\end{array}$ & $\begin{array}{l}B C A \\
\text { LGD }\end{array}$ & 2 & 1 & 1 & 3 & $\begin{array}{l}+ \\
+\end{array}$ & \pm & $\begin{array}{r}14.37 \\
0.40\end{array}$ & $\begin{array}{l}3+ \\
1+\end{array}$ \\
\hline $\begin{array}{l}3 \\
3 \\
3 \\
3 \\
3\end{array}$ & $\begin{array}{l}\text { BCA } \\
\text { HGD } \\
G G D \\
\text { IM } \\
N\end{array}$ & 1 & 0 & $\times$ & 3 & $\begin{array}{l}- \\
= \\
- \\
-\end{array}$ & $\begin{array}{l}- \\
z \\
z \\
-\end{array}$ & $\begin{array}{l}1.02 \\
0.37 \\
0.75 \\
0.53 \\
0.92\end{array}$ & $\begin{array}{l}1+ \\
1+ \\
1+ \\
1+ \\
1+\end{array}$ \\
\hline $\begin{array}{l}4 \\
4\end{array}$ & $\begin{array}{l}\text { BCA } \\
\mathrm{HGD}\end{array}$ & 1 & 0 & $\times$ & 3 & + & - & $\begin{array}{l}0.38 \\
0.31\end{array}$ & $\begin{array}{l}0 \\
0\end{array}$ \\
\hline $\begin{array}{l}5 \\
5 \\
5 \\
5\end{array}$ & $\begin{array}{l}\text { BCA } \\
\mathrm{HGD} \\
\mathrm{G} \mathrm{GD} \\
\mathrm{N}\end{array}$ & 1 & 0 & $\times$ & 2 & $\begin{array}{l}- \\
- \\
-\end{array}$ & $\begin{array}{l}- \\
z \\
z\end{array}$ & $\begin{array}{l}0.59 \\
0.53 \\
0.60 \\
0.45\end{array}$ & $\begin{array}{l}1+ \\
1+ \\
1+ \\
1+\end{array}$ \\
\hline $\begin{array}{l}6 \\
6 \\
6\end{array}$ & $\begin{array}{l}\mathrm{BCA} \\
\mathrm{HGD} \\
\mathrm{N}\end{array}$ & 1 & 0 & $x$ & 2 & $\begin{array}{l}+ \\
+ \\
+\end{array}$ & $\begin{array}{l}+ \\
+ \\
-\end{array}$ & $\begin{array}{r}16.97 \\
3.70 \\
0.57\end{array}$ & $\begin{array}{l}3+ \\
3+ \\
0\end{array}$ \\
\hline $\begin{array}{l}7 \\
7 \\
7 \\
7 \\
7\end{array}$ & $\begin{array}{l}\text { BCA } \\
\text { HGD } \\
\text { LGD } \\
\text { IM } \\
N\end{array}$ & 1 & 0 & $\times$ & 3 & $\begin{array}{l}+ \\
+ \\
- \\
-\end{array}$ & $\begin{array}{l}- \\
- \\
- \\
-\end{array}$ & $\begin{array}{l}0.38 \\
0.50 \\
0.37 \\
0.80 \\
0.79\end{array}$ & $\begin{array}{l}1+ \\
1+ \\
1+ \\
1+ \\
1+\end{array}$ \\
\hline $\begin{array}{l}8 \\
8\end{array}$ & $\begin{array}{l}\mathrm{BCA} \\
\mathrm{HGD}\end{array}$ & 2 & 1 & $x$ & 3 & + & - & $\begin{array}{l}1.02 \\
0.47\end{array}$ & $\begin{array}{l}2+ \\
1+\end{array}$ \\
\hline $\begin{array}{l}9 \\
9\end{array}$ & $\begin{array}{l}\mathrm{BCA} \\
\mathrm{HGD}\end{array}$ & 1 & 0 & $x$ & 2 & $\begin{array}{l}+ \\
+\end{array}$ & $\begin{array}{c}- \\
-\end{array}$ & $\begin{array}{l}0.70 \\
0.77\end{array}$ & $\begin{array}{l}2+ \\
2+\end{array}$ \\
\hline $\begin{array}{l}10 \\
10 \\
10\end{array}$ & $\begin{array}{l}B C A \\
L G D \\
I M\end{array}$ & 1 & 0 & $x$ & 3 & $\begin{array}{l}+ \\
+ \\
+\end{array}$ & $\begin{array}{l}\bar{z} \\
\overline{-}\end{array}$ & $\begin{array}{l}0.69 \\
1.20 \\
\text { n.d. }\end{array}$ & $\begin{array}{l}2+ \\
1+ \\
0\end{array}$ \\
\hline $\begin{array}{l}11 \\
11\end{array}$ & $\mathrm{BCA}^{\mathrm{B}}$ & 1 & 0 & $\times$ & 2 & + & - & $\begin{array}{l}0.50 \\
0.36\end{array}$ & $0^{1+}$ \\
\hline $\begin{array}{l}12 \\
12\end{array}$ & $\begin{array}{l}\mathrm{BCA} \\
\mathrm{HGD}\end{array}$ & 3 & 1 & $x$ & 2 & $\begin{array}{l}+ \\
+\end{array}$ & \pm & $\begin{array}{l}5.64 \\
0.82\end{array}$ & $\begin{array}{l}3+ \\
1+\end{array}$ \\
\hline $\begin{array}{l}13 \\
13 \\
13\end{array}$ & $\begin{array}{l}\mathrm{BCA} \\
\mathrm{HGD} \\
\mathrm{N}\end{array}$ & 2 & 1 & $x$ & 3 & $\begin{array}{l}+ \\
+\end{array}$ & $\begin{array}{l}\bar{y} \\
\overline{-}\end{array}$ & $\begin{array}{r}4.06 \\
2.35 \\
-1.10\end{array}$ & $\begin{array}{l}2+ \\
2+ \\
0\end{array}$ \\
\hline $\begin{array}{l}14 \\
14 \\
14\end{array}$ & $\begin{array}{l}\text { BCA } \\
\text { HGD } \\
\text { HGD II }\end{array}$ & 1 & 0 & 1 & 2 & $\begin{array}{l}+ \\
+ \\
+\end{array}$ & $\begin{array}{l}+ \\
+ \\
+\end{array}$ & $\begin{array}{l}5.42 \\
3.67 \\
6.24\end{array}$ & $\begin{array}{l}3+ \\
3+ \\
3+\end{array}$ \\
\hline $\begin{array}{l}15 \\
15\end{array}$ & $\mathrm{BCA}_{\mathrm{N}}$ & 1 & 0 & $x$ & 3 & + & $\overline{-}$ & $\begin{array}{l}0.79 \\
1.70\end{array}$ & $\begin{array}{l}1+ \\
1+\end{array}$ \\
\hline $\begin{array}{l}16 \\
16\end{array}$ & $\begin{array}{l}\text { BCA } \\
\text { IM }\end{array}$ & 1 & 0 & $x$ & 2 & \pm & $\overline{-}$ & $\begin{array}{l}0.27 \\
\text { n.d. }\end{array}$ & $\begin{array}{l}1+ \\
0\end{array}$ \\
\hline $\begin{array}{l}17 \\
17\end{array}$ & $\mathrm{BCA}^{\mathrm{B}}$ & 1 & 0 & $x$ & 2 & + & $\stackrel{+}{-}$ & $\begin{array}{l}7.09 \\
0.97\end{array}$ & $\begin{array}{l}3+ \\
0\end{array}$ \\
\hline $\begin{array}{l}18 \\
18 \\
18 \\
18\end{array}$ & $\begin{array}{l}B C A \\
H G D \\
G G D \\
N=\end{array}$ & 1 & 0 & $\times$ & 2 & $\begin{array}{c}\text { n.d. } \\
+ \\
- \\
-\end{array}$ & $\begin{array}{c}\text { n.d. } \\
- \\
-\end{array}$ & $\begin{array}{l}\text { n.d. } \\
0.51 \\
1.20 \\
0.69\end{array}$ & $\begin{array}{l}\text { n.d. } \\
1+ \\
1+ \\
1+\end{array}$ \\
\hline $\begin{array}{l}19 \\
19\end{array}$ & $\mathrm{BCA}_{\mathrm{N}}$ & 3 & 1 & $\times$ & 3 & - & - & $\begin{array}{l}1.09 \\
1.50\end{array}$ & $\begin{array}{l}1+ \\
1+\end{array}$ \\
\hline $\begin{array}{l}20 \\
20 \\
20\end{array}$ & $\begin{array}{l}\text { BCA } \\
\text { HGD } \\
\text { LGD }\end{array}$ & 1 & 0 & $x$ & 2 & $\begin{array}{c}\text { n.d. } \\
+ \\
+\end{array}$ & $\begin{array}{c}\text { n.d. } \\
+ \\
-\end{array}$ & $\begin{array}{r}\text { n.d. } \\
29.96 \\
1.50\end{array}$ & $\begin{array}{l}\text { n.d. } \\
3+ \\
1+\end{array}$ \\
\hline 21 & $\mathrm{BCA}$ & 3 & 0 & $\times$ & 1 & + & + & 37.01 & $3+$ \\
\hline 22 & $\mathrm{BCA}$ & 3 & 1 & $\times$ & 3 & + & - & 0.80 & $1+$ \\
\hline $\begin{array}{l}23 \\
23\end{array}$ & $\mathrm{BCA}_{\mathrm{N}}$ & 3 & 1 & $\times$ & 3 & + & - & $\begin{array}{l}4.53 \\
0.74\end{array}$ & $0^{2+}$ \\
\hline $\begin{array}{l}24 \\
24\end{array}$ & $\mathrm{BCA}_{\mathrm{N}}$ & 3 & 1 & $x$ & 3 & + & \pm & $\begin{array}{r}83.57 \\
1.10\end{array}$ & $\begin{array}{l}3+ \\
0\end{array}$ \\
\hline $\begin{array}{l}25 \\
25\end{array}$ & $\mathrm{BCA}_{\mathrm{N}}$ & 3 & 1 & $\times$ & 3 & + & + & $\begin{array}{r}10.29 \\
0.40\end{array}$ & $\begin{array}{l}3+ \\
0\end{array}$ \\
\hline
\end{tabular}

pT, the extent of the primary tumor; pN, the absence or presence and extent of regional lymph node metastasis; M, the absence or presence of distant metastasis; $\mathrm{G}$, tumor differentiation grade; n.d., not done.

Lesions: BCA, Barrett's adencarcinoma; HGD, high grade dysplasia; LGD, low grade dysplasia; IM, intestinal metaplasia; N, squamous epithelium.

${ }^{a}$ Data of eight amplified BCA samples are also part of an exclusive methodological study of quantitative gene expression analysis in microdissected archival formalin-fixed and paraffin-embedded tumor tissue (Specht et al, 2001).

${ }^{b}$ Polysomy 17 and Her-2/neu gene amplification detected by FISH; QRT-PCR, mean value of quantitative reverse transcriptase polymerase chain reaction for Her-2/neu mRNA; IHC, immunohistochemistry for c-erbB2 oncoprotein according to the DAKO scoring system. 
Table 2. Her-2/neu Status for FISH, QRT-PCR, and IHC in 23 Cases of Barrett's Adenocarcinoma

\begin{tabular}{lrr}
\hline & $\mathrm{n}$ & $\%$ \\
\hline FISH $^{a}$ & 3 & 13 \\
Disomy & 12 & 52 \\
Polysomy 17 & 8 & 35 \\
$\quad$ Her-2/neu amplification & & \\
mRNA level & \\
Normal level & 13 & 56 \\
Moderate overexpression $_{\text {Strong overexpression }}$ & 2 & 9 \\
IHC $^{a}$ & 8 & 35 \\
0 & & \\
$1+$ & 2 & 9 \\
$2+$ & 8 & 35 \\
$3+$ & 5 & 22 \\
& 8 & 35 \\
\hline
\end{tabular}

${ }^{a}$ For definitions see "Materials and Methods" section.

sive immunostaining were present in some cases. Those four samples of HGD with Her-2/neu gene amplification also displayed an overexpression; however, lower mRNA levels were seen than in BCA (mean: 10.89). Uniformly, in all of these amplified BCA and $\mathrm{HGD}$ samples, a strong oncoprotein expression (DAKO score $3+$ ) was present. Two HGD lesions obtained from one patient (Case 14) displayed both Her-2/neu gene amplification and strong oncoprotein overexpression $(3+)$ in the majority of tumor cells, however, different levels of mRNA overexpression (relative mRNA values: 3.67 and 6.24) were observed. FISH analysis of these HGD lesions revealed heterogeneity of intralesional gene copy number changes, showing populations with different fractions of cells with polysomy 17 and Her-2/neu gene amplification. IHC also revealed minor cell populations with less intensive membranous staining.

The 12 BCA samples showing a polysomy 17 without Her-2/neu gene amplification displayed a normal mRNA expression (mean, 1.26); however, in two BCA samples, moderately elevated mRNA levels (4.53 and 4.06) were detected. Nine HGD and LGD areas showed a polysomy 17 . All of these samples showed a normal mRNA level (mean, 0.98), except one HGD sample showing a slightly elevated mRNA expression (value of 2.35). In all of these BCA, HGD, and LGD samples with polysomy 17 without Her-2/neu gene amplification, no (DAKO score 0 and 1) or weak (DAKO score 2) oncoprotein expression was observed.

All samples of squamous epithelium $(n=13)$, the areas of IM $(n=2)$, and the areas of LGD $(n=4)$ that showed no changes at the DNA level displayed a normal mRNA expression (mean of squamous epithelium: 0.87; mean of IM: 0.67; mean of LGD: 0.73). All of these samples were scored as negative or slightly positive $(0$ or $1+)$ for oncoprotein expression.

\section{Discussion}

In the present study, the Her-2/neu status was evaluated for the first time in the histologically proposed metaplasia-dysplasia-adenocarcinoma sequence simultaneously at the DNA, mRNA, and oncoprotein level. A precondition for the quantification of Her-2/ neu mRNA expression levels in small samples of histologically well-defined precursor lesions was the application of QRT-PCR combined with laser-assisted microdissection in archival formalin-fixed, paraffinembedded tissue samples, recently reported from our group (Specht et al, 2001). The real-time QRT-PCR has emerged as an easy, versatile, sensitive, as well as accurate and precise, method for the study of gene expression (Gibson et al, 1996; Heid et al, 1996). Real-time systems are capable of detecting PCR products as they accumulate during amplification, and the reactions are characterized by the point during cycling when PCR amplification is still in the exponential phase, thus enabling precise quantitation of RNA over a wide dynamic range. This technique allowed us to compare quantitative mRNA expression of Her-2/ neu with DNA and protein levels in the metaplasiadysplasia-adenocarcinoma sequence of BCA.

Her-2/neu gene amplification was found in $35 \%$ of BCA samples, and all of these samples were uniformly associated with strong overexpression of both mRNA and protein $(3+)$ levels. Previous immunohistochemical studies reported Her-2/neu overexpression in invasive $\mathrm{BCA}$ varying widely from $11 \%$ to $73 \%$ (alKasspooles et al, 1993; Flejou et al, 1994; Hardwick et al, 1995; Jankowski et al, 1992), possibly reflecting the well-known inherent problems of IHC in quantitation and interpretation for the Her-2/neu status (Press et al, 1994). A recent report described Her-2/neu gene amplification by $\mathrm{FISH}$ in $19 \%$ of $\mathrm{BCA}$ investigated (Brien et al, 2000). These authors have applied a DNA probe specific for the Her-2/neu gene locus, which does not allow one to distinguish a locus-specific amplification from a polysomy of chromosome 17 (Walch et al, 2000b). However, this may be important because aneuploid or increased tetraploid populations occur in more than $90 \%$ to $95 \%$ of BCA (Barrett et al, 1999). Therefore, the high prevalence of a polysomy 17 without Her-2/neu gene amplification in our cases of BCA (52\%) is not surprising and should be distinguished from a locus-specific amplification of the Her-2/neu gene. Those BCA samples with a polysomy 17 but without a locus-specific amplification for Her-2/neu demonstrated a normal or only moderately elevated mRNA expression (relative mRNA values: $0.27-4.53$ ) and no or only moderate protein overexpression $(0-2+)$. In contrast, a strong membranous staining pattern $(3+)$ combined with highly elevated mRNA expression (relative mRNA values: $>5$ ) was uniformly associated with a locus-specific Her-2/neu gene amplification. Thus, a polysomy 17 without a locus-specific Her-2/neu gene amplification does not induce strong mRNA and protein overexpression. Although not yet sufficiently examined, a Her-2/neu gene amplification and a polysomy of chromosome 17 may be of different biological significance. Our observations are also supported by those from Jimenez et al (2000) who found that Her-2/neu gene copy numbers higher than four and less than 10 were usually asso- 

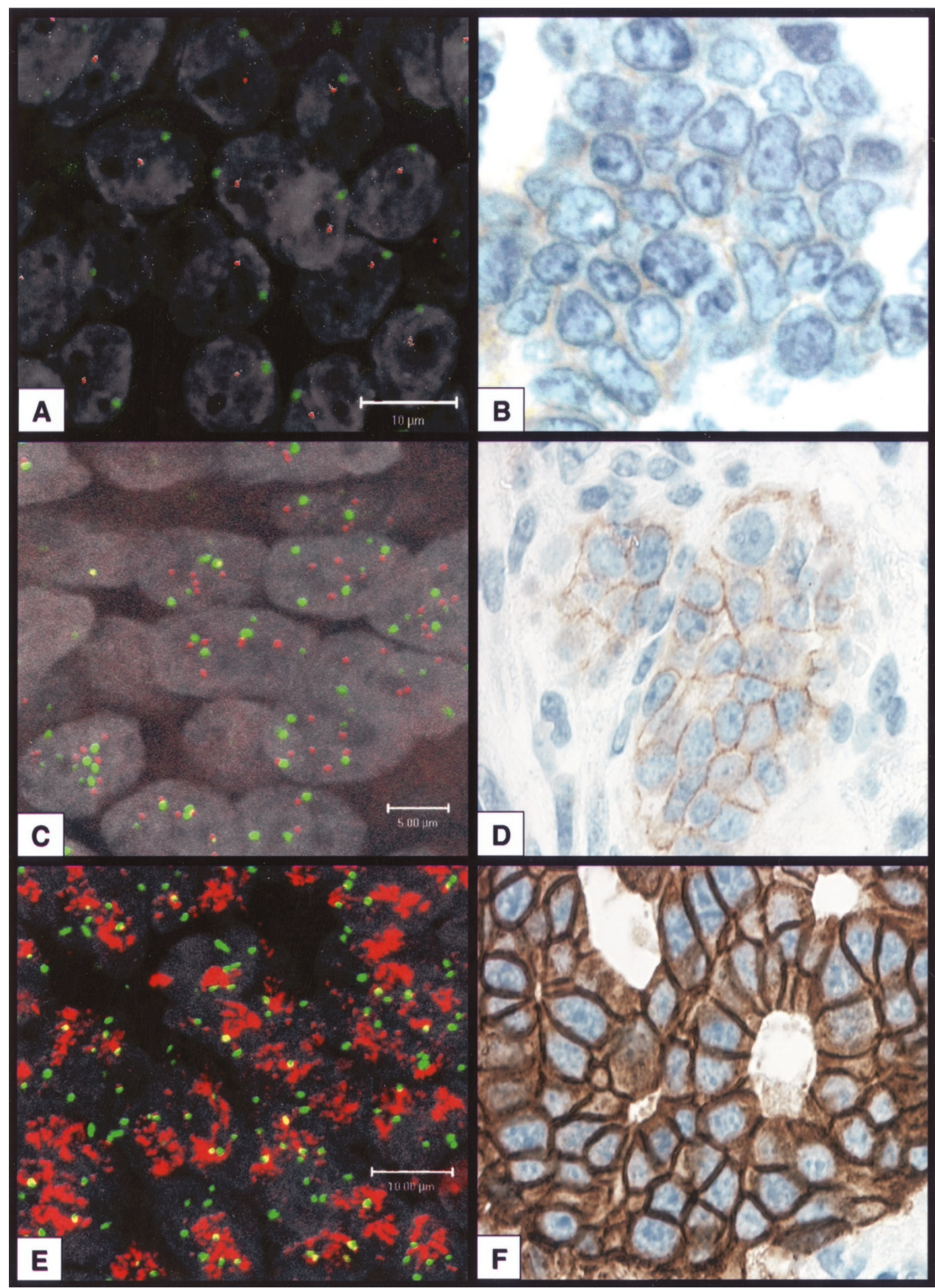

\section{Figure 1.}

Comparison of dual-color fluorescence in situ hybridization (FISH) for HER-2/neu and centromere 17 and immunohistochemical staining for Her-2/neu protein expression in corresponding areas of three cases of Barrett's adenocarcinoma (BCA) (A/B, C/D, E/F). The fluorescent-labeled DNA probes are specific for the HER-2/neu gene locus (17q11.2-q12, red signals) and for the alpha satellite DNA sequence at the centromeric region of chromosome 17 (17p11.1-q11.1, green signals); tumor nuclei are counterstained with DAPI (gray). The image acquisition was performed with a laser scanning microscope (LSM 510, Zeiss, Germany). A Tumor cells with normal signal counts of the Her-2/neu gene locus and centromere 17 are shown. The corresponding immunohistochemical staining is negative (0) for HER-2/neu protein (B). C, Most tumor cells show more than four green (centromere 17) and red (HER-2/neu gene locus) signals. There are equal numbers of green and red signals in the same cell, indicating a polysomy of chromosome 17. Those tumor cells displayed a weak positive $(2+)$ or no $(0-1+)$ immunohistochemical staining pattern (D). Note the bright HER-2/neu gene clusters (red confluent signals marked by arrows) in E, suggesting a high-level gene amplification. Those amplified tumor cells uniformly demonstrated a strong protein overexpression $(3+)$ as shown in $\mathrm{F}$. 


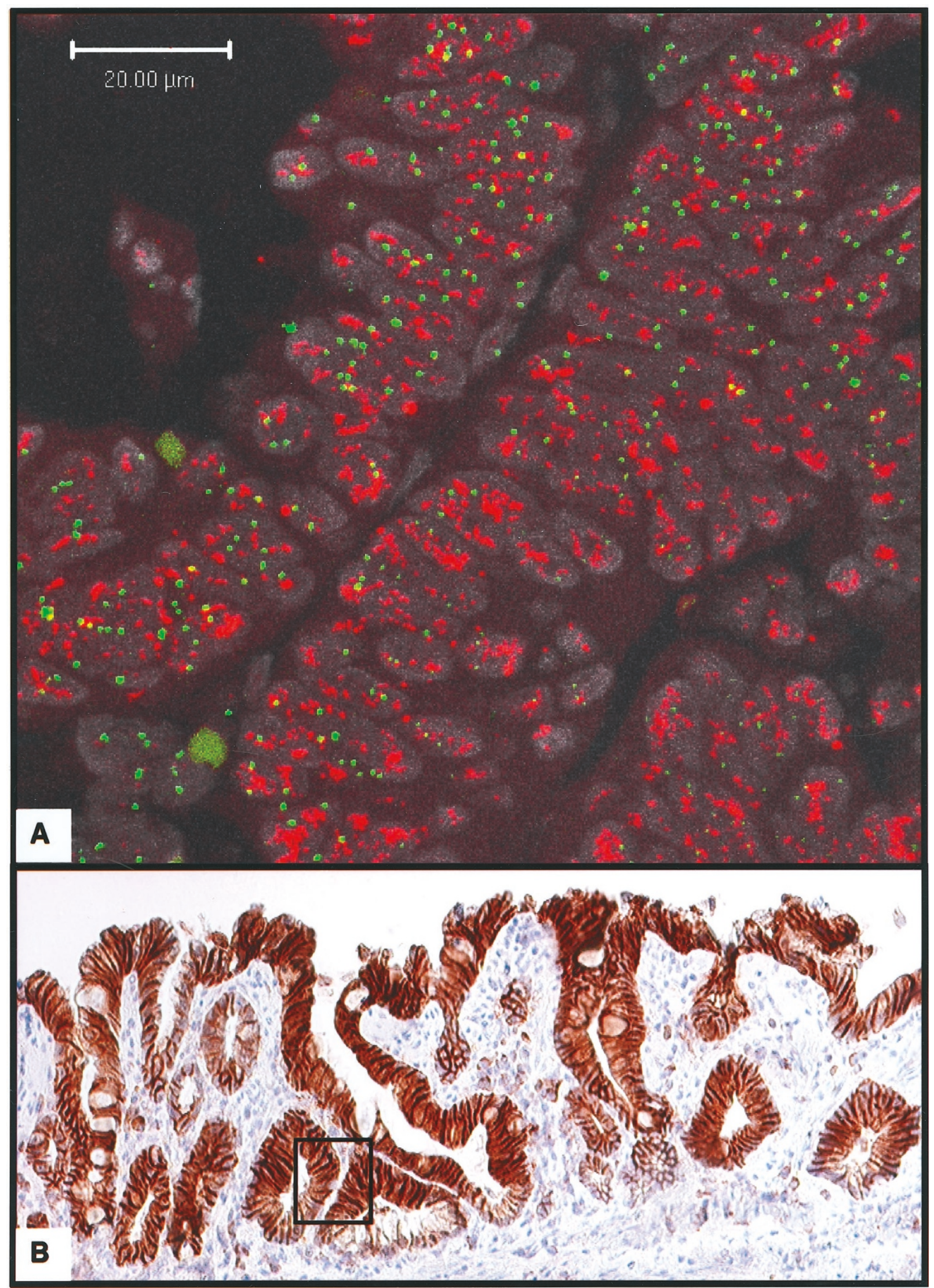

Figure 2.

Her-2/neu gene amplification and strong protein overexpression in a high-grade dysplasia (HGD) area. Note the red confluent Her-2/neu signals, indicating an amplification (A). The corresponding cell group immunohistochemically stained for Her-2/neu protein is marked in B. 


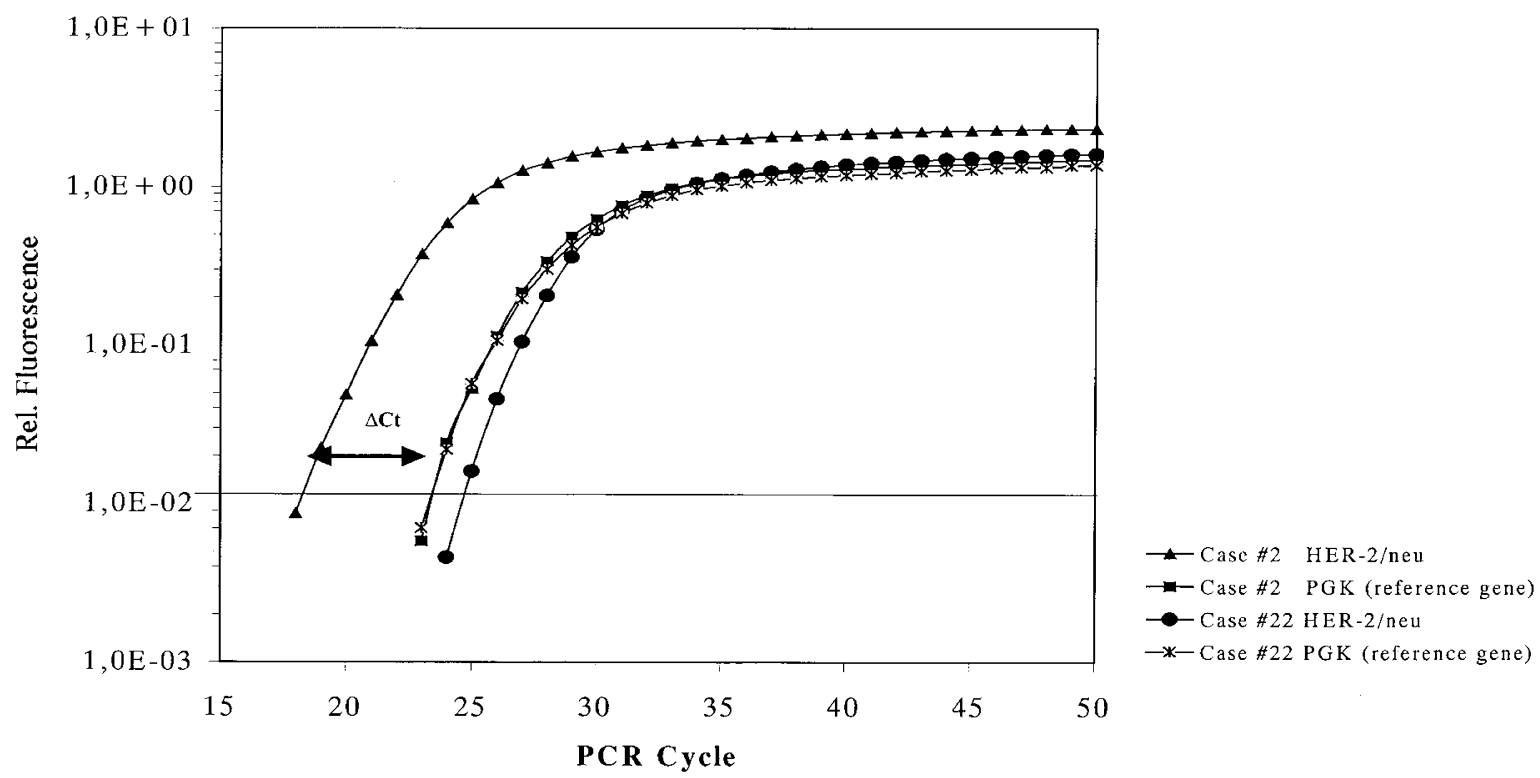

Figure 3.

Her-2/neu and phosphoglycerokinase (PGK) mRNA amounts by real-time reverse-transcriptase polymerase chain reaction (RT-PCR) in two cases of BCA. Case 2 shows strong overexpression of Her-2/neu mRNA, indicated by a low Ct value in the amplification plot as compared with Case 22, which displays normal Her-2/neu mRNA levels. The difference between the Ct for PGK and the Ct for Her-2/neu ( $\Delta \mathrm{Ct})$ corresponds to the relative expression level of Her-2/neu.

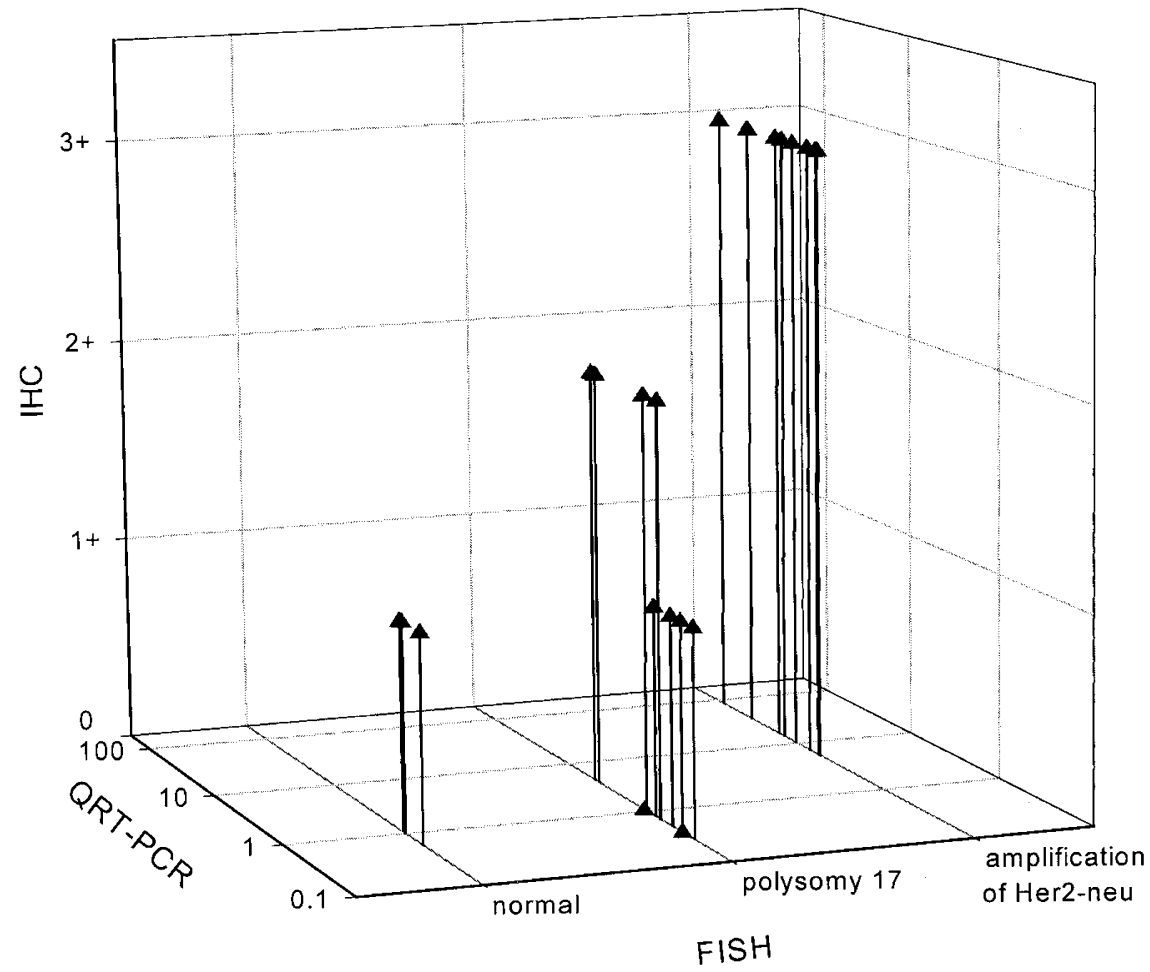

Figure 4.

Her-2/neu status in 23 BCA areas at the DNA, mRNA, and protein level. Note, only BCA cases showing Her-2/neu gene amplification and strong mRNA overexpression present a strong protein overexpression $(3+)$. IHC, immunohistochemistry; QRT-PCR, quantitative reverse-transcriptase polymerase chain reaction; FISH, fluorescence in situ hybridization.

ciated with chromosome 17 polysomy in breast cancer but not with high-level protein overexpression. This may be of high clinical interest because the intermediate category of immunohistochemical staining $(2+)$ in breast cancer, known to be subject to variable interpretation and the response to serotherapy in those cases is uncertain (Jimenez et al, 2000).

Four of 13 areas of HGD were found to be amplified for the Her-2/neu gene, and five presented a polysomy 17 without Her-2/neu gene amplification. The ampli- 

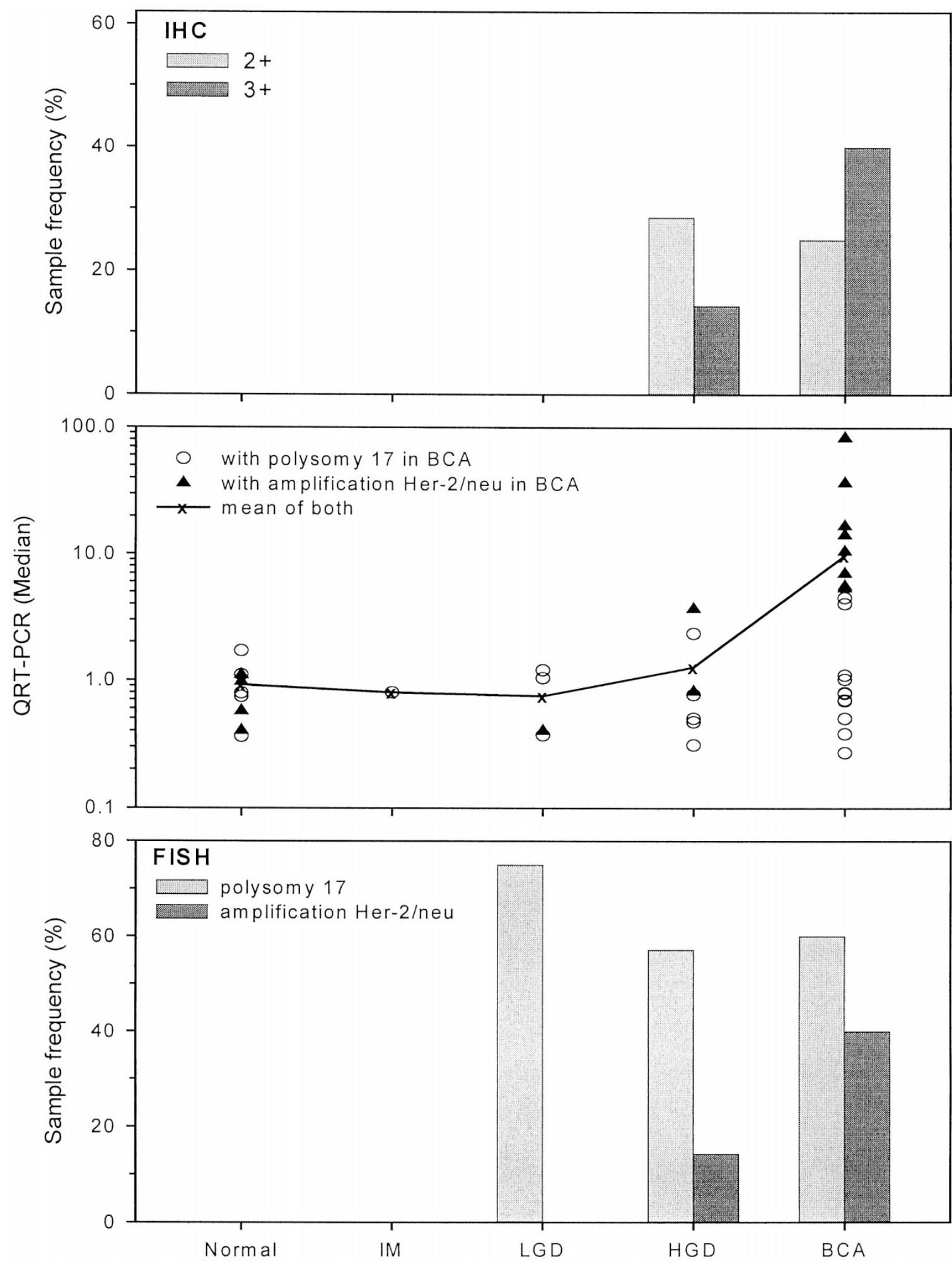

Figure 5.

Polysomy of chromosome 17, Her-2/neu gene amplification, mRNA expression and oncoprotein expression in the metaplasia-dysplasia-adenocarcinoma sequence of those cases with Her-2/neu gene amplification or polysomy 17 in BCA. IHC, immunohistochemistry; 2+, weak to moderate Her-2/neu expression; 3+, strong Her-2/neu overexpression; QRT-PCR, quantitative reverse-transcriptase polymerase chain reaction; $F I S H$, fluorescence in situ hybridization; $B C A$, Barrett's adenocarcinoma; $H G D$, high-grade dysplasia; $L G D$, low-grade dysplasia; IM, intestinal metaplasia.

fied areas showed overexpression of mRNA (relative mRNA values, 3.7-29.9) and a strong positivity $(3+)$ by IHC. Two HGD lesions obtained from one patient
(Case 14) displayed both Her-2/neu gene amplification and strong oncoprotein overexpression, however, different levels of mRNA overexpression were observed. 
FISH analysis of these two HGD lesions revealed heterogeneity of intralesional gene copy number changes showing populations with different fractions of cells with polysomy 17 and Her-2/neu gene amplification, which was also shown by a varying staining pattern in IHC. This is a reflection of genetic heterogeneity, recently reported in BCA and HGD at the DNA and protein level (Walch et al, 2000a), which in the present study is now also detectable at the RNA level. No sample of LGD showed a locus-specific Her-2/neu amplification, but polysomy 17 was present in four of eight cases. Galipeau et al (1996) reported that aneuploid or increased tetraploid populations are already present in premalignant Barrett's epithelium. Thus, the observed polysomy 17 in LGD and HGD lesions without a Her-2/neu gene amplification may be a result of early polyploidization, preceding the later genetic events, such as oncogene amplification. Furthermore, additional oncogenes on chromosome $17 \mathrm{q}$ may be involved in the carcinogenesis of BCA. Recently, we described DNA copy number gains on chromosome 17q12-q25 in HGD and even LGD by comparative genomic hybridization (Walch et al, 2000c). These data suggest the presence of additional oncogenes that are amplified in the neighborhood of the Her-2/neu locus (17q21) and have not yet been identified. No alterations of Her-2/neu at the DNA, mRNA, and protein level and no changes of chromosome 17 were detected in BCA-associated intestinal metaplasia and normal-appearing squamous epithelium.

In summary, only a locus-specific Her-2/neu gene amplification was associated with strong mRNA overexpression and strong membranous Her-2/neu immunostaining in BCA and HGD. A chromosome 17 polysomy, as found in the majority of BCA, led to no or weak mRNA overexpression and no or weak immunopositivity. In the metaplasia-dysplasia-adenocarcinoma sequence, a chromosome 17 polysomy without Her-2/neu gene amplification was already present in LGD. This may be a result of an early polyploidization, preceding the later genetic events, such as Her-2/neu gene amplification in HGD and BCA.

\section{Material and Methods}

\section{Tissue Samples}

All analyses were performed on archival material from formalin-fixed (4\% buffered formalin) and paraffinembedded tissue obtained from 25 patients with primary BCA of the distal esophagus. All patients underwent an esophagectomy without preoperative radiotherapy or chemotherapy. Hematoxylin and eosin (H\&E)-stained slides from the resection specimens were re-evaluated independently by two pathologists (MW, AW) for the identification of IM, columnar epithelial dysplasia (LGD or HGD), tumor differentiation grade (well, moderate, poor), and depth of tumor invasion. BCA and precursor lesions were diagnosed according to the WHO classification (Werner et al, 2000). The BCA were classified according to the Union Internationale Contre le Cancer TNM system (Her- manek and Sobin, 1997). Serial sections were cut for FISH $(10 \mu \mathrm{m}), \mathrm{IHC}(5 \mu \mathrm{m})$, and tissue microdissection $(5 \mu \mathrm{m})$. The first and the last section of each series (FISH, IHC, and microdissection) were stained with H\&E. Corresponding areas on sequential sections were investigated by the three methods.

\section{FISH}

For FISH analysis, a PathVysion Her-2/neu DNA probe kit (Vysis; Downers Grove, United Kingdom) was used according to the manufacturer's recommendations. The kit consists of directly labeled fluorescent DNA probes specific for the Her-2/neu gene locus (17q11.2-q12) and a DNA probe specific for the alpha satellite DNA sequence at the centromeric region of chromosome 17 (17p11.1-q11.1). Tissue pretreatment was performed as previously described (Werner et al, 1999). Counterstaining of nuclei was performed using diaminobenzidine (DAPI). Nuclei from normal squamous epithelium or lymphocytes deposited separately on the same slide were used as controls of hybridization efficiency and specificity.

An improved evaluation method of each lesion was necessary because of two aspects that are particularly important in BCA and its precursors lesions. First, a special amplification pattern as Her-2/neu "signal clusters" usually with more than 10 confluent signals (an example is given in Fig. 1E) was observed as previously described (Ishikawa et al, 1997; Walch et al, 2000a). Although a gene amplification as "homogeneously stained regions" is clearly evident, this pattern does not allow a precise signal enumeration. Second, $\mathrm{BCA}$ and its precursor lesions display intralesional genetic heterogeneity to varying degrees (Walch et al, 2000a). Thus, the standard evaluation method of counting signals of only 200 randomly selected nuclei, disregarding the total size of the tumor, is insufficient. Therefore, in this study the whole area of each neoplastic lesion present in the tissue section was evaluated independently by two investigators (AW, KB) with a fluorescence microscope (Zeiss Axiovert 100 M; Carl Zeiss, Jena, Germany) in high power fields (HPF; magnification $600 \times$ ). The Her-2/neu gene locus was classified as amplified if there were more than twice the number of red Her-2/neu signals than green centromere 17 signals (ratio $>2: 1$ ) per cell nucleus. Her-2/neu signal clusters with more than 10 confluent signals in cell nuclei were observed as distinct amplification patterns (Ishikawa et al, 1997). More than two nuclear red signals accompanied by the same number of nuclear green signals was considered to be indicative of polysomy of chromosome 17 (ratio 1:1). Following these criteria, the cell population of each HPF was classified as displaying a disomy, a polysomy 17 , or an amplification for Her-2/neu gene. The results of all HPF were listed and finally categorized for the total area. An amplification for the Her-2/neu gene of the total lesion was diagnosed analogously to the threshold of the DAKO-Score system (see "IHC" section) if at least $10 \%$ of the evaluated areas displayed this type of change. A polysomy was diagnosed if more than $50 \%$ 
of all areas showed more than two nuclear red signals accompanied by the same number of nuclear green signals. Finally, representative areas of each sample were documented using a laser scanning microscope (LSM 510, Carl Zeiss) as described previously (Walch et al, 2000a). Examples are shown in Figure 1, A, C, and $E$, and Figure 2. Each of the malignant and premalignant lesions corresponding to those for $\mathrm{IHC}$ and QRT-PCR were evaluated.

\section{Real-Time QRT-PCR for Her-2/neu}

Tissue Microdissection. An ultraviolet laser microbeam (P.A.L.M., Wolfratshausen, Germany) was used to excise precisely defined tissue areas on H\&E stained $5 \mu \mathrm{m}$ sections as previously described (Walch et al, 2000b). For the HER-2/neu analyses, at least 1,000 cells were microdissected from normal cells (squamous epithelium) IM, LGD, HGD, and BCA.

RNA Extraction and Reverse Transcription. Microdissected cells were directly transferred into a sterile 1.5-ml tube and dissolved in $200 \mu \mathrm{l}$ RNA lysis buffer containing $10 \mathrm{~mm}$ Tris-HCL pH 8.0, $100 \mu \mathrm{M}$ EDTA, 2\% SDS pH 7.3, and $500 \mu \mathrm{g} / \mathrm{ml}$ proteinase K (Sigma, St. Louis, Missouri), and incubated at $60^{\circ} \mathrm{C}$ for 16 hours until the tissue was completely solubilized. RNA was purified by phenol and chloroform extractions, followed by precipitation with an equal volume of isopropanol in the presence of $1 \mu \mathrm{l}$ of $10 \mathrm{mg} / \mathrm{ml}$ carrier glycogen at $-20^{\circ} \mathrm{C}$. The RNA pellet was washed once in $70 \%$ ethanol, dried, and resuspended in $20 \mu \mathrm{l}$ RNase-free water. Twelve microliters of RNA was reverse-transcribed in a final volume of $20 \mu \mathrm{l}$ using 200 U M-MLV reverse transcriptase (GIBCO-BRL, Gaithersburg, Maryland) in the manufacturer's buffer containing $1 \mu$ l of dNTPs (10 mm each), $40 \cup$ RNase inhibitor (Roche, Mannheim, Germany), and 300 ng random hexamers (Roche) at $37^{\circ} \mathrm{C}$ for 60 minutes, followed by $95^{\circ} \mathrm{C}$ for 5 minutes.

Real Time QRT-PCR. Real-time QRT-PCR analyses were performed using HER-2/neu and phosphoglycerokinase (PGK)-specific primers and probes with the $A B I$ PRISM 7700 Sequence Detection System instrument and software (PE Applied Biosystems, Foster City, California). The principle of real-time RT-PCR has been described elsewhere (Gibson et al, 1996; Heid et al, 1996). Sequences of the intron-spanning primers and probe that were used for amplification of the HER-2/neu cDNA are as follows: 5'-CCAGGACCTGCTGAACTGGT-3' (300 nм final concentration) 5'-TGTACGAGCCGCACATCC-3' (50 nm final concentration) and FAM-CAGATTGCCAAGGGGATGAGCTACCTG-TAMRA (200 nm final concentration). PGK primers and probe were purchased from PE Applied Biosystems (Weiterstadt, Germany). PCR was carried out with the TaqMan Universal PCR Master Mix (PE Applied Biosystems) using $3 \mu$ l of cDNA in a $30 \mu$ final reaction mixture. The cycling conditions included an initial incubation at $50^{\circ} \mathrm{C}$ for 2 minutes, followed by 10 minutes at $95^{\circ} \mathrm{C}$ and 50 cycles of 15 seconds at $95^{\circ} \mathrm{C}$, and 1 minute at $60^{\circ} \mathrm{C}$. Experiments were performed in duplicate for each sample. Relative expression of the HER-2/neu mRNA levels was calculated using the relative standard curve method (Perkin-Elmer Corporation, 1997) with PGK as a reference gene.

The mean level of Her-2/neu mRNA expression in normal squamous epithelium (13 samples) was 0.92 . Her-2/neu mRNA expression in tumor tissue was arbitrarily classified as normal (relative QRT-PCR value: $0-1$ ), moderately elevated (relative QRT-PCR value: $\geq 2-4$ ), and strongly overexpressed (relative QRT-PCR value: $\geq 5$ ).

IHC. The sections for immunohistochemistry were deparaffinized and rehydrated. Antigen retrieval was performed as described previously (Walch et al, 2000a). After cooling the sections to room temperature, endogenous peroxidase activity was blocked by incubation with $3 \%$ hydrogen peroxidase in methanol for 15 minutes. The sections were then incubated for 15 minutes with PBS containing $10 \%$ serum at $37^{\circ} \mathrm{C}$. Anti-c-erbB-2 antibody (DAKO, Glostrup, Denmark) was applied at a dilution of 1:400 and incubated for 1 hour at $25^{\circ} \mathrm{C}$ followed by detection with a DAKO ChemMate detection kit containing peroxidase and $\mathrm{DAB}$, according to the manufacturer's recommendations. Finally, the slides were counterstained with hematoxylin, dehydrated and coverslipped. To ensure the sensitivity of the reaction, a case of invasive ductal breast carcinoma with known overexpression of c-erbB-2 was used as positive control.

c-erbB-2 oncoprotein expression was evaluated by two pathologists (MW, AW) according to a score system recommended by the DAKO HercepTest. Briefly, complete lack of staining or membranous staining in less than $10 \%$ of the tumor cells was scored as 0 . If faint or barely perceptible membranous staining was detected in more than $10 \%$ of the tumor cells or cells showed only partial membranous staining, they were scored as $1+$. A score of $2+$ was defined as weak to moderate staining of the entire membrane in more than $10 \%$ of the tumor cells. Strong staining of the entire membrane in more than $10 \%$ of the tumor cells was scored as $3+$.

\section{References}

al-Kasspooles M, Moore $\mathrm{JH}$, Orringer MB, and Beer DG (1993). Amplification and over-expression of the EGFR and erbB-2 genes in human esophageal adenocarcinomas. Int $\mathrm{J}$ Cancer 54:213-219.

Barrett MT, Sanchez CA, Prevo LJ, Wong DJ, Galipeau PC, Paulson TG, Rabinovitch PS, and Reid BJ (1999). Evolution of neoplastic cell lineages in Barrett oesophagus. Nat Genet 22:106-109.

Brien TP, Odze RD, Sheehan CE, McKenna BJ, and Ross JS (2000). HER-2/neu gene amplification by FISH predicts poor survival in Barrett's esophagus-associated adenocarcinoma. Hum Pathol 31:35-39.

Flejou JF, Paraf F, Muzeau F, Fekete F, Henin D, Jothy S, and Potet $F$ (1994). Expression of c-erbB-2 oncogene product in Barrett's adenocarcinoma: Pathological and prognostic correlations. J Clin Pathol 47:23-26. 
Galipeau PC, Cowan DS, Sanchez CA, Barrett MT, Emond MJ, Levine DS, Rabinovitch PS, and Reid BJ (1996). 17p (p53) allelic losses, 4N (G2/tetraploid) populations, and progression to aneuploidy in Barrett's esophagus. Proc Natl Acad Sci USA 93:7081-7084.

Gibson UE, Heid CA, and Williams PM (1996). A novel method for real time quantitative RT-PCR. Genome Res 6:995-1001.

Hardwick RH, Shepherd NA, Moorghen M, Newcomb PV, and Alderson D (1995). c-erbB-2 overexpression in the dysplasia/carcinoma sequence of Barrett's oesophagus. J Clin Pathol 48:129-132.

Heid CA, Stevens J, Livak KJ, and Williams PM (1996). Real time quantitative PCR. Genome Res 6:986-994.

Hermanek P and Sobin LH (1997). Classification of malignant tumors. Berlin, New York: Springer-Verlag, 71-80.

Ishikawa T, Kobayashi M, Mai M, Suzuki T, and Ooi A (1997). Amplification of the c-erbB-2 (HER-2/neu) gene in gastric cancer cells: Detection by fluorescence in situ hybridization. Am J Pathol 151:761-768.

Jankowski J, Coghill G, Hopwood D, and Wormsley KG (1992). Oncogenes and onco-suppressor gene in adenocarcinoma of the oesophagus. Gut 33:1033-1038.

Jimenez RE, Wallis T, Tabasczka P, and Visscher DW (2000). Determination of Her-2/neu status in breast carcinoma: Comparative analysis of immunohistochemistry and fluorescent in situ hybridization. Mod Pathol 13:37-45.

Perkin-Elmer Corporation (1997). ABI Prism 7700 Sequence Detection System: Relative quantitation of gene expression. User Bulletin 2. Norwalk, CT: Perkin-Elmer Corporation.

Press MF, Hung G, Godolphin W, and Slamon DJ (1994). Sensitivity of HER-2/neu antibodies in archival tissue samples: Potential source of error in immunohistochemical studies of oncogene expression. Cancer Res 54:2771-2777.
Ross JS and Fletcher JA (1998). The HER-2/neu oncogene in breast cancer: Prognostic factor, predictive factor, and target for therapy. Stem Cells 16:413-428.

Specht K, Richter T, Müller U, Walch A, Werner M, and Höfler $H$ (2001). Quantitative gene expression analysis in microdissected archival formalin-fixed and paraffin-embedded tumor tissue. Am J Pathol 158:419-429.

Walch A, Bink K, Gais P, Stangl S, Hutzler P, Aubele M, Mueller J, Höfler H, and Werner M (2000a). Evaluation of c-erbB-2 overexpression and Her-2/neu gene copy number heterogeneity in Barrett's adenocarcinoma. Anal Cell Pathol 20:25-32.

Walch A, Bink K, Hutzler P, Höfler H, and Werner M (2000b). HER-2/neu gene amplification by FISH predicts poor survival in Barrett's esophagus-associated adenocarcinoma (Letter). Hum Pathol 31:1332-1334.

Walch A, Zitzelsberger H, Bruch J, Keller G, Angermeier D, Aubele M, Mueller M, Stein H, Braselmann H, Siewert JR, Höfler H, and Werner M (2000c). Chromosomal imbalances in Barrett's adenocarcinoma and in the metaplasia-dysplasiacarcinoma-sequence. Am J Pathol 156:555-566.

Werner A, Mattis M, Aubele M, Cummings C, Zitzelsberger H, Hutzler P, and Hofler H (1999). 20q13.2 amplification in intraductal hyperplasia adjacent to in situ and invasive ductal carcinoma of the breast. Virchows Arch 435:469-472.

Werner M, Flejou JF, Hainaut P, Höfler H, Lambert R, Keller $\mathrm{G}$, and Stein HJ (2000). Adenocarcinoma of the oesophagus. In: Aaltonen LA, Hamilton S, Kleihues P, Sobin LH, editors. WHO Classification of Tumours. Pathology and Genetics of Tumours of the Digestive System. Berlin, New York: Springer-Verlag, 16-22. 